\title{
The empire strikes back? China's new racial sovereignty
}

\author{
By Ruben Gonzalez-Vicente \\ Available at: $\underline{\text { https://doi.org/10.1016/j.polgeo.2016.11.001 }}$
}

Keywords: China; nationalism; sovereignty; racism; international relations.

"In the best of Chinese traditions, generations of overseas Chinese never forget their home country, their origins, or the blood of the Chinese nation flowing in their veins" (Xi Jinping, 2014: 69)

It is often argued that the territoriality of China's ancient empire was flexible and defined along cultural lines. The Middle Kingdom was constructed not only through conquest and suzerainty but also through cultural practices that enabled Chinese scholars to draw and claim the "borders of Chinese civilization" (Howland, 1996). Things changed in the $19^{\text {th }}$ and $20^{\text {th }}$ centuries as the sovereignty of the Chinese state adapted to external demands and became infused with nationalist rationales. However, civilizational myths and ambitions held sway, and have permeated the social construction of the country's "imagined community" up to our present day. Today, the People's Republic of China positions itself as a guardian of Westphalian sovereignty and a proponent of a problematical norm of inter-national "non-interference" (GonzalezVicente, 2015). Yet the prevalence of differentiated "zoning technologies" within the PRC (Ong, 2004), the "graded rings of sovereignty" employed to claim and flexibly manage Hong Kong, Macau and Taiwan (Sow, 2013), and the resolve to annex the South China Sea indicate that issues of territoriality and sovereignty are not as settled or discrete as the official discourse may suggest. At the same time, Chinese ethno-nationalism remains marred by a racial essentialism that portrays "the Han as a pure biological entity" (Dikötter, 2015, p. 78), and that inevitably precludes many of those who inhabit within China's variegated borders from belonging to the imagined community.

In this piece I argue that these understandings of the postcolonial nation, operating against a backdrop of rising economic and political power, have translated in a series of alarming interventions that I characterize as 'extraterritorial racial sovereignty'. This form of sovereignty draws upon an assemblage of imperial, civilizational and racist understandings of "Chineseness", and has been mobilized by the Chinese government to intervene beyond state borders. Crucially, racial sovereignty is espoused with geographical markers and notions such as that of a "Greater China" and with ideas of a cultural and diasporic identity that ostensibly dissociate the nation from territory. However, these ideas have been operationalized by the state in order to circumvent territorial constraints and expand its disciplinary power, hence producing new forms of state spatiality that assist in the consolidation of territorial claims and the policing of dissent. Whereas the idea of "Greater China" - which includes in most interpretations the PRC, Taiwan, Hong Kong, Macau, Singapore and overseas Chinese communities - is best understood as a contingent and ambiguous discourse (Callahan 2004), the Chinese government has in recent times used it as an actual site of intervention, ultimately projecting an ambition to operate both in a territorially discrete realm and an extraterritorial and racially-bounded dimension. Three examples are used to illustrate this trend: the abduction in Thailand and Hong Kong of book publishers critical of the Chinese government; the extradition of Taiwanese citizens from Kenya to China; and the Chinese government's claim to protect Malaysian citizens of Chinese descent.

The first of these cases has gathered significant attention, as the disappearance of the booksellers signaled an escalation in China's recent campaign against dissent. A total of five

\footnotetext{
${ }^{1}$ There is a distinction in Chinese language between "zhongguoren" (中国人-a Chinese national) and “huaren" (华人-a person of Chinese ethnicity). This editorial focuses on the PRC's intent to govern over non-Chinese citizens of Chinese descent.
} 
publishers of gossipy books about Chinese leaders vanished to later reappear in the custody of PRC authorities confessing to a series of crimes that were unrelated to their publishing activities. Foreign media, rights groups and close relatives took such confessions with skepticism, suggesting that they had likely been forced and staged (The Guardian, 2016a). Most prominent were the cases of Gui Minhai, a Swedish citizen, and Lee Bo, British. Gui disappeared in Thailand, while Lee was abducted in Hong Kong, both beyond the jurisdiction of PRC law enforcers. What is remarkable about these cases is how PRC authorities justified - while not openly acknowledging - the extraterritorial detentions of non-Chinese nationals. China's Foreign Minister contended that Lee's Chinese descent and the fact that he resided in Hong Kong made him "first and foremost a Chinese citizen" (South China Morning Post, 2016). Soon after his detention, Lee appeared on China's Phoenix TV to express his intention to give up British citizenship. In an almost synchronized move, Gui published a letter where he requested the Swedish government not to intervene in his case, claiming he truly felt Chinese and "[his] roots [were] still in China" (Reuters, 2016). Both declarations, coming from mouth and pen of long-time dissidents, seemed to project the Chinese government's notion of citizenship rather than the identity or interests of the detainees.

The second case involves not just racial paradigms but also geopolitical motivations - which can in turn be analyzed against the backdrop of race. Adhering to its longstanding "One China" policy and seeking to make a stance after the electoral victory of Taiwan's pro-independence Democratic Progressive Party (DPP), the PRC government accepted the deportation of eight Taiwanese citizens from Kenya to China following a case of phone-frauds in early 2016. As Taiwanese authorities protested vividly, China's official media denounced the DPP and proclaimed that "it is indisputable, both in law and in the One China policy, that the Chinese mainland can extradite the eight Taiwanese involved in the fraud charges" (Global Times, 2016). The case needs to be framed within the PRC's quest for "reunification" of "Greater China" both controversial concepts in that they infer inexorability, as well as racial, cultural, economic and ultimately political unity (Harding, 1993). Race has been a pillar of Chinese nationalism since Sun Yat-sen's proposition for a nation-race built on the force of "common blood" and lineage (Dikötter, 1996). The racial foundations of the imagined nation engender a geopolitical construct (ie. "Greater China") that transcends existing territorial borders. Yet while racial essentialism has been prominent throughout China's modern history, the actual implementation of race-based forms of extraterritorial sovereignty is a more recent affair that reflects the advance of assertive nationalism under the leadership of Xi Jinping.

The "manufactured (...) myth of shared descent", traced back to the Yellow Emperor and the Peking Man (Leibold, 2006, p. 211), features prominently in contemporary nationalist discourses. This is illustrated in the way in which Chinese diplomats have recently invoked the association between the Chinese state and the broader "Chinese family" across the world. A rather innocuous but revealing example is that of China's Consul General in San Francisco, Luo Linquan, who speaking to an audience of children adopted by American parents in December 2015 reminded them that their "black eyes, black hair and dark skin" were all signs of Chineseness, and exhorted them to "develop the Chinese spirit [they] were born with" (China Daily, 2015). A more explicit discourse of extraterritorial sovereignty can be appreciated in the declarations of China's ambassador in Malaysia, Huang Huikang. Responding to anti-Chinese protests in Kuala Lumpur's Chinatown, Huang warned that China would "not sit by idly" if the rights of ethnic Chinese were to be violated, despite the fact that most inhabitants of Chinatown are today Malaysian citizens (The Economist, 2015). Here it is important to note how ethnic Chinese in Southeast Asia are conceived in the dominant imagination in China as "huaqiao" (华侨 - overseas Chinese), literally expounding them as part of China's diasporic nation and as 'bridges' (qiao) to assist with the country's economic and civilizational ambitions. In this way, imagined biological ties produce a distinct architecture of state power that is to some extent delinked from territory and which ultimately legitimizes intervention. 
In setting an agenda for the research of actual practices of extraterritorial racial sovereignty in China's international relations, I suggest to explore whether two distinct notions of "empire" open a useful path for analysis. The first of these notions is that of "empire" as a pre-modern mode of political organization in China. This is a pre-national empire, one where the European idea of "bounded communities" with marked (and mapped) territoriality was not yet overtly present (Anand, 2009). Common intellectual references, clan and lineage, everyday rituals and cultural norms delimited the non-territorial borders of the empire, whereas a sophisticated bureaucratic structure was key in political organization (Spence, 1990, pp. 10-11). Official narratives in contemporary China echo this rather idealized imperial past. The very ideas of lineage and shared history seem to be very much alive in the minds of the China's new leaders. On this count, Xi Jinping's "China Dream" does not suggest a complete departure from a backward past, as Mao once did, but instead builds upon the idea of a shared lineage to urge "the sons and daughters of the Chinese nation" to achieve "the rejuvenation of the Chinese nation [...], the greatest dream of the Chinese people since the advent of modern times" (Xi, 2014, p. 38).

The deterritorialization of state power is in turn inspired by the revival of pre-national concepts such as "Tianxia" (天下 - All-under-Heaven), revisited by Chinese scholars to claim a vernacular contribution to world-making based on notions of hierarchy, harmony, order and the "uniformity of society" (Zhao, 2011, p. 26). While the idea of "Tianxia" evokes universality, it is also deeply civilizational. The term in its original use referred only to the "Chinese world" ruled by an emperor or "Tianzi" (天子 - Son of Heaven). Yet in its cosmopolitan aspirations, it is presented as an ordering rational without which we are condemned to living in a "disordered world of chaos (...) [a world that] is not yet a world, but is still a nonworld" (ibid, p. 33). Such ethno-cultural narratives and myths legitimize intervention not only as a matter of territorial security but also as a civilizational imperative. This suggests that, beyond the modern racial, national and territorial rationales that began to take hold in $19^{\text {th }}$ century China, one can explore deeper into the genealogy of Chinese political thought to understand how extraterritorial racial sovereignty is thought, justified, and put in practice nowadays (see Callahan 2008 for a critique of Chinese visions of world order).

A promising way to do so is to explore how China, as a "postcolonial informal empire", selectively appropriates "ideas and technologies such as sovereignty and nationalism" - and also pre-modern ones - to justify the deployment of center-periphery relations within its borders (Anand, 2012, p. 68), but also to expand its ethnocentric civilizational enterprise beyond territorial boundaries. This perspective also allows us to probe into the messy and utilitarian combination of vernacular rationales of political organization with practices that could be better analyzed from the perspective of "empire" in the modern European sense. Contemporary forms of imperialism legitimize extraterritorial intervention as a matter of internal and global security for markets or the citizens of a given country. China's emerging extraterritorial sovereignty combines notions of non-territorial racial citizenship with contemporary logics of territorial integrity and securitization, although Chinese interventions are aimed not only at securitizing but also at disciplining the imagined community. The question of race is central to the articulation of 'citizenship' in contemporary China, as one can clearly observe in Hong Kong's policies for naturalization, which overtly privilege individuals of Chinese descent, and hence delineates the parameters of extraterritorial intervention. In effect, three distinct forms of citizenship overlap each other: legal citizenship, a sense of lineage and biological belonging, and a territorially encompassing form of domination that allows to incorporate Tibetans and Uighurs to a multiethnic national project, albeit on unequal terms. The combination of these three distinct ordering rationales, based on pre-modern and modern understandings of political organization, justify in turn interventions to securitize the legal, racial and territorial nation.

China's increasingly assertive racial discourse and the de-linking of territory and state citizenship from sovereignty challenge not only political geography theorizing, but also 
existing structures of state power in Asia and beyond. As China's economic and military power rise through the $21^{\text {st }}$ century, ethnic-Chinese populations across the world may feel growing pressures to remain loyal to the Chinese government's centralized vision of a unitary "China Dream". The governments of other countries may concede to the nationalist ambitions of China and disregard international law or their responsibilities towards their citizens, as the active role of the Kenyan government in the case of Taiwanese deportations or the timid response of Britain in Lee Bo's case seem to indicate. It remains uncertain whether these discourses and interventions will intensify with time, but China's emerging practices of extraterritorial racial sovereignty are relevant today, and could reveal much about the country's future role in regional and global politics. 


\section{References:}

Anand, D. (2009) 'Strategic hypocrisy: The British Imperial scripting of Tibet's geopolitical identity', The Journal of Asian Studies 68(1): 227-252.

Anand, D. (2012) 'China and India: Postcolonial informal empires in the emerging global order', Rethinking Marxism 24(1): 68-86.

Callahan, W.A. (2004) Contingent States: Greater China and Transnational Relations, Minneapolis: University of Minnesota Press

Callahan, W.A. (2008) 'Chinese visions of the world order: Post-hegemonic or a new hegemony?”, International Studies Review 10: 749-61.

China Daily (2015) 'US adoptive families thanked for opening homes', 7 December, available at http://www.chinadaily.com.cn/world/2015-12/07/content_22656291.htm.

Dikötter, F. (1996) 'Culture, "race", and nation: The formation of national identity in twentieth century China', Journal of International Affairs 49(2): 590-605.

Dikötter, F. (2015) The Discourse of Race in Modern China, New York: Oxford University Press.

Harding, H. (1993) 'The concept of "Greater China": Themes, variations and reservations', The China Quarterly 136: 660-686.

Howland, D.R. (1996) Borders of Chinese Civilization: Geography and History and Empire's End, Durham \& London: Duke University Press.

Global Times (2016) 'Kenya right to extradite Taiwan suspects to mainland', 13 April, available at http://www.globaltimes.cn/content/978308.shtml.

Gonzalez-Vicente, R. (2015) 'The limits to China's non-interference foreign policy: Pro-state interventionism and the rescaling of economic governance', Australian Journal of International Affairs 69(2): 205-223.

Leibold, J. (2006) 'Competing narratives of racial unity in republican China: From the Yellow Emperor to Peking Man’, Modern China 32(2): 181-220.

Ong, Aihwa (2004) 'The Chinese axis: Zoning technologies and variegated sovereignty', Journal of East Asian Studies 4: 69-96.

Reuters (2016) 'Missing Hong Kong bookseller in China to answer 11 year-old conviction state media', 17 January, available at http://www.reuters.com/article/china-bookselleridUSL3N15109L.

South China Morning Post (2016) “First and foremost a Chinese citizen': China's foreign minister on missing Hong Kong bookseller who also holds British passport', 5 January, available at http://www.scmp.com/news/hong-kong/law-crime/article/1898106/first-andforemost-chinese-citizen-chinas-foreign-minister.

Sow, K.T. (2013) Managing China's Sovereignty in Hong Kong and Taiwan, New York: Palgrave Macmillan.

Spence, J.D. (1990) The Search for Modern China, New York: W.W. Norton. 
The Economist (2015) 'Banyan: Big motherland', 10 October, p. 28.

The Guardian (2016a) 'Missing Hong Kong bookseller 'confesses' on Chinese state TV', 17 January, available at http://www.theguardian.com/world/2016/jan/17/missing-hong-kongbookseller-gui-minhai-reappears-on-chinese-tv.

The Guardian (2016b) “Missing' Hong Kong bookseller Lee Bo says he will give up British citizenship', 29 February, available at http://www.theguardian.com/world/2016/feb/29/missing-british-bookseller-appears-ontelevision.

Xi Jinping (2014) The Governance of China, Beijing: Foreign Languages Press.

Zhao, T.Y. (2011) 'Rethinking Empire from the Chinese concept "All-under-Heaven" (Tianxia, 天下)', in W.A. Callahan and E. Barabantseva (eds.), China Orders the World: Normative Soft Power and Foreign Policy (pp. 21-36), Washington: Woodrow Wilson Center Press. 